\title{
Meningkatkan Hasil Belajar Mahasiswa Melalui E-Modul Berbasis Android
}

\section{Anni Faridah1*, Widya Afridiani2}

\author{
1,2,3 Universitas Negeri Padang, Padang, Indonesia
}

\section{ART ICLE IN F O}

Article history:

Received August 19, 2021

Revised August 20, 2021

Accepted October 30, 2021

Available online December 25, 2021

Kata Kunci:

E-modul, Android, Hasil Belajar

Keywords:

E-module, Android, Learning

Outcomes

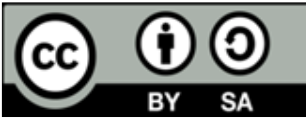

This is an open access article under the CC BY-SA license.

Copyright () 2021 by Author. Published by Universitas Pendidikan Ganesha.

\section{A BS TRACT}

\begin{abstract}
A B S T R A K
Mahasiswa dalam pembelajaran daring kurang termotivasi untuk belajar mandiri dikarenakan proses pembelajaran yang monoton. Hal berimbas kepada mahasiswa mengalami kesulitan dalam memahami materi Food Control dikarenakan keterbatasan sumber belajar yang tersedia. Tujuan dari penelitian ini adalah untuk mengembangkan E-modiul berbasis Android pada mata kuliah Food Control yang valid, praktis dan efektif. Jenis penelitian ini yaitu pengembangan. Metode penelitian yang digunakan adalah Research and Development (R\&D) dengan prosedur pengembangan 4-D (Define, Design, Develop, Desseminate). Subjek penelitiannya adalah mahasiswa yang berjumlah 29 orang Metode yang digunakan untuk mengumpulkan data yaitu wawancara, observasi, kuesioner, dan tes. Instrument yang digunakan untuk mengumpulkan data yaitu kuesioner dan lembar tes. Teknik yang digunakan untuk menganalisis data yaitu statistic deskriptif kualitatif dan kuantitatif. Hasil yang diperoleh dari penelitian pengembangan ini adalah e-modul berbasis Android sudah efektif dilihat berdasarkan hasil belajar mahasiswa. Berdasarkan perbedaan hasil pre test dan post test dengan ketuntasan klasikal sebesar 96,55 \%. Dapat disimpulkan bahwa e-modul layak diterapkan dalam proses pembelajaran dan efektif meningkatkan hasil belajar mahasiswa. Berdasarkan temuan penelitian ini disimpulkan bahwa e-modul berbasis Android dinyatakan efektif untuk dimanfaatkan sebagai sumber belajar pendukung pembelajaran daring pada mata kuliah Food Control. Implikasi penelitian ini yaitu E-modul dapat diterapkan oleh dosen untuk mengatasi mahasiswa yang kesulitan dalam belajar.
\end{abstract}

\begin{abstract}
Students in online learning are less motivated to study independently due to the tedious learning process. It resulted in students experiencing difficulties understanding Food Control material due to the limited learning resources available. This research aims to develop an Android-based E-module in Food Control courses that are valid, practical, and effective. This type of research is development. The research method used is Research and Development (R\&D) with 4-D development procedures (Define, Design, Develop, Disseminate). The research subjects were 29 students. The methods used to collect data were interviews, observations, questionnaires, and tests. The instruments used to collect data are questionnaires and test sheets. The technique used to analyze the data is descriptive qualitative and quantitative statistics. The results obtained from this development research are that the Android-based e-module has been effectively seen based on student learning outcomes. Based on the difference in the pre-test and post-test results with classical completeness of $96.55 \%$. It can be concluded that the e-module is feasible to be applied in the learning process and effectively improves student learning outcomes. Based on the findings of this study, it was concluded that the Androidbased e-module was declared effective to be used as a learning resource to support online learning in the Food Control course. This research implies that lecturers can apply E-modules to overcome students who have difficulties in learning.
\end{abstract}

\section{PENDAHULUAN}

Pendidikan di Indonesia mengalami perkembangan yang pesat. Hal tersebut dapat dilihat dari metode pembelajaran yang diterapkan semakin bervariasi mengikuti perkembangan teknologi yang semakin pesat (Devi et al., 2016; Pratama \& Retnawati, 2018; Tiwery et al., 2021). Pembelajaran daring 
merupakan sebuah inovasi pendidikan yang melibatkan unsur teknologi informasi dalam pembelajaran (Fitriyani et al., 2020; Fortuna et al., 2020; Susilowati \& Azzasyofia, 2020). Pembelajaran daring atau juga yang dikenal dengan pembelajaran online dapat dilakukan dimana saja dan kapan saja dengan bantuan internet dan dukungan perangkat mobile antara lain smartphone atau android, iphone, tablet ,laptop dan lain sebagainya (Dewa et al., 2020; Slovaček \& Čosić, 2020). Implementasi pembelajaran daring mengalami percepatan dalam pelaksanaannya yang disebabkan oleh pandemic global Covid -19 yang melanda dunia. Semua jenjang pendidikan dimulai dari pendidikan anak usia dini hingga perguruan tinggi harus beralih dari pembelajaran tatap muka menjadi pembelajaran jarak jauh (daring) dari rumah (Abidah et al., 2020; Yusuf Siregar \& Amiril Akbar, 2020). Pembelajaaran daring dapat dijadikan solusi pembelajaran jarak jauh ketika terjadi bencana alam. Pembelajaran daring dengan bantuan teknologi diharapkan dapat mendukung mahasiswa dalam belajar mandiri di masa pandemi, kemudahan dalam mengakses pembelajaran dan peningkatan hasil belajar (Onyema, 2020; Syarifudin, 2020). Hal ini yang menyebabkan media pembelajaran sangat diperlukan dalam pembelajaran.

Namun pada kenyataannya masih banyak guru yang belum menerapkan media pembelajaran (Laksana, 2020; Setianingsih et al., 2019; Surata et al., 2020). Masalah ini juga ditemukan pada salah satu universitas. Berdasarkan hasil observasi dan wawancara yang dilakukan di Universitas Negeri Padang ditemukan bahwa mahasiswa Food Control B dalam pembelajaran daring kurang termotivasi untuk belajar mandiri dikarenakan proses pembelajaran yang monoton. Hal berimbas kepada mahasiswa mengalami kesulitan dalam memahami materi Food Control dikarenakan keterbatasan sumber belajar yang tersedia. Selain itu, bahan ajar yang tersedia sangat sederhana dan kurang mendukung pembelajaran secara mandiri. Mahasiswa perlu memiliki perangkat pembelajaran yang mendukung dan mampu melihat bahwa sistem pembelajaran daring yang fleksibel mampu membentuk kemandirian belajar dan motivasi belajar mahasiswa (Febliza \& Okatariani, 2020; Lyashenko \& Malinina, 2015; Padmadewi, 2015). Berdasarkan uraian dan permasalahan pada mata kuliah Food Control prodi Ilmu Kesejahteraan Keluarga di Universitas Negeri Padang diatas, mahasiswa membutuhkan suatu sumber belajar berupa modul pembelajaran Food Control dimana sudah terangkum keseluruhan materi yang harus mereka pelajari. Pemilihan media yang tepat tentu sangat berpengaruh terhadap berhasil tidaknya sebuah proses belajar mengajar (Candra Lestari, 2018; Puspitarini \& Hanif, 2019; Triwahyuningtyas et al., 2020). Penggunaan media bahan ajar yang dapat mendukung pembelajaran daring sangat dibutuhkan untuk meningkatkan motivasi mahasiswa dalam melakukan pembelajaran daring (Sriyanti et al., 2021; Triwahyuningtyas et al., 2020). Media ajar yang dapat digunakan peserta didik untuk belajar mandiri adalah dalam bentuk modul. Inovasi metode atau media dalam pembelajaran daring dapat menjadi upaya meningkatkan efektivitas pembelajaran daring (Asmi et al., 2018; Mastroleo et al., 2020). Sejalan dengan Pengembangan media pembelajaran melalui smartphone dibuat dengan teknologi yang sederhana namun efektif yang dapat digunakan dengan mudah oleh siswa sebagai alat atau media dalam proses pembelajaran daring (Jang et al., 2021; Sahin \& Yilmaz, 2020; Wungguli \& Yahya, 2020).

Penggunaan e-module memberikan kemudahan baik dosen maupun mahasiswa untuk mempelajari materi ajar, khususnya jika menerapkan pembelajaran secara tidak langsung (asynchronous) dengan memanfaatkan digital learning (Irwansyah et al., 2017; Triwahyuningtyas et al., 2020). E-modul yang digunakan oleh dosen bertujuan untuk mentransfer pembelajaran dari dosen kepada mahasiswa sehingga merangsang pikiran, perasaan, minat hingga kemauan mahasiswa untuk belajar (Asmi et al., 2018; Sriyanti et al., 2021; Winatha et al., 2018). Modul elektronik memiliki banyak kelebihan, diantaranya mampu menyajikan modul dengan lebih menarik (S. Y Ningsih \& Mahyuddin, 2021; Sofyan et al., 2019). E-modul diharapkan dapat meningkatkan minat, motivasi, keaktifan serta mampu meningkatkan pemahaman peserta didik terhadap pembelajaran. Berdasarkan temuan penelitian ini disimpulkan bahwa e-modul berbasis Android pada dinyatakan valid untuk dimanfaatkan sebagai alat bantu pembelajaran pada mata kuliah Food Control. Modul pembelajaran yang akan dikembangkan berupa e-modul berbasis aplikasi Android yang nantinya akan dapat digunakan oleh mahasiswa menggunakan telepon pintar (Smartphone) yang mereka miliki. Hal ini dipertimbangkan karena e-modul yang digunakan menggunakan handphone dapat diakes mahasiswa dimana saja serta dapat diakses kapan saja (Aprilia \& Suryadarma, 2020; Aufa et al., 2021; Hamzah \& Mentari, 2017). Penggunaan e-modul praktis dibawa kemana saja dan dibuat dengan tampilan yang menarik dapat memudahkan mahasiswa dalam belajar mandiri dan menarik perhatian untuk membaca. Penelitian sebelumnya juga menyatakan bahwa pembelajaran menggunakan e-modul juga mempermudah pelaksanaan pembelajaran, karena dapat digunakan tidak hanya ketika proses pembelajaran di dalam kelas secara tatap muka saja (face-toface learning) juga dapat digunakan dimana saja dan kapan saja (Fisnani et al., 2020; Logan et al., 2021; Sunismi \& Fathani, 2016). Temuan penelitian lainnya juga menyatakan bahwa E-modul akan meningkatkan hasil belajar siswa (Sri Yunimar Ningsih \& Mahyuddin, 2021; Raharjo et al., 2017; Suarsana 
\& Mahayukti, 2013). Diharapkan penggunaan handphone dikalangan pelajar lebih bermanfaat kearah yang lebih bermanfaat khususnya pada pembelajaran. Tujuan penelitian ini yaitu mengembangkan e-modul pembelajaran berbasis android diharapkan dapat menjadi kontribusi positif bagi mahasiswa dan dosen agar pembelajaran menjadi variatif, kreatif dan tidak monoton. E-modul yang akan dikembangkan menjadi sumber pembelajaran inovasi darurat selama wabah Covid-19 yang mampu memfasilitasi siswa untuk belajar secara mandiri.

\section{METODE}

Penelitian ini menggunakan model pengembangan Four-D. Model ini dipilih karena mempunyai prosedur yang sederhana, dan sistematis, sesuai dengan langkah-langkah penelitian pengembangan yang peneliti lakukan, serta dalam pengembangannya melibatkan penilaian ahli sehingga sebelum di ujicoba media yang dikembangkan telah dilakukan revisi berdasarkan penilaian, saran, dan masukan para ahli. Pengumpulan data dilaksanakan dengan bantuan instrument berupa soal yang dibagikan kepada mahasiswa untuk menilai kemampuan mahasiswa seusai aspek kognitif Sumber data pada penelitian ini berasal dari data primer yang di dapatkan secara langsung dari mahasiswa yang diambil melalui efektivitas e-modul yang dikembangkan. Subjek penelitiannya adalah mahasiswa semester IV prodi Ilmu Kesejahteraan Keluaraga Fakultas Pariwisata dan Perhotelan Universitas Negeri Pandang yang berjumlah 29 orang. Analisis data efektivitas e-modul pembelajaran dilaksanakan melalui pre test dan post test dengan ketuntasan klasikal dan gain score. Metode yang digunakan untuk mengumpulkan data yaitu wawancara, observasi, kuesioner, dan tes. Instrument yang digunakan untuk mengumpulkan data yaitu kuesioner dan lembar tes. Ketuntasan belajar secara klasikal yaitu mengukur tingkat keberhasilan ketuntasan belajar mahasiswa secara menyeluruh. Kriteria Ketuntasan Minimal (KKM) untuk mata kuliah Food Control di Universitas Negeri Padang yaitu sebesar 70 dengan Nilai Mutu C (Cukup) berdasarkan ketentuan ketuntasan individual yang diperoleh mahasiswa. Ketuntasan belajar klasikal dinyatakan berhasil jika persentase mahasiswa yang tuntas belajar atau siswa yang mendapat nilai $\geq 70$ jumlahnya lebih besar atau sama dengan 85\% dari jumlah mahasiswa seluruhnya. Jadi, e-modul dikatakan efektif jika tingkat kelulusan mahasiswa sama atau lebih dari 85\%. Kemudian Untuk menghitung Gain Score subjek uji coba diberikan dulu tes awal (pre-test) dan tes akhir sesudah pembelajaran (post-test). Setelah memperoleh data ketuntasan mahasiswa secara individual, selanjutnya menentukan jumlah keseluruhan mahasiswa yang mencapai ketuntasan.

\section{HASIL DAN PEMBAHASAN}

Hasil

E-modul berbasis Android yang dikembangkan ini berbasis pada model pengembangan 4D yang terdiri dari empat tahapan, yakni: define, design, develop, dan disseminate. Pada tahap pertama yaitu define, dilaksanakan seperti analisis kebutuhan, analisis mahasiswa, analisis silabus, analisis konsep dan rumusan tujuan pembelajaran. Analisis kebutuhan dilakukan bertujuan untuk mengobservasi masalah awal dan mengetahui hambatan yang ditemui dalam proses pembelajaran Food Control. Analisis mahasiswa merupakan telaah terhadap karakteristik mahasiswa meliputi tingkat perkembangan intelektual dan motivasi belajar. Kemudian Analisis silabus dilakukan terhadap capaian pembelajaran dan Standar Kompetensi pada mata kuliah Food Control. Analisis ini dilakukan untuk melihat cakupan materi, tujuan yang ingin dicapai dari pembelajaran, dan strategi pembelajaran Food Control yang digunakan dalam pembelajaran. Hasil analisis ini digunakan sebagai landasan dalam mengembangkan Emodul pembelajaran Food Control. Analisis konsep bertujuan untuk mengidentifkasi konsep-konsep utama yang akan digunakan dan mengidentifikasi konsep pendukung yang relevan dan berkaitan dengan materi Food Control dalam pengembangan e-modul pembelajaran berbasis Android. Kemudian Perumusan tujuan pembelajaran dimaksudkan untuk menentukan materi-materi yang dikembangkan pada e-modul pembelajaran.

Pada tahap kedua yaitu design, dilakukan pemilihan media dilakukan untuk mengidentifikasi media pembelajaran yang tepat untuk menyajikan materi yang disampaikan. Adapun dalam penelitian ini dipilih e-modul berbasis Android dengan menggunakan software android studio. Kegiatan utama dari tahap ini adalah menulis, menelaah, dan menyusun E-modul yang dirancang dengan memperhatikan bahasa, susunan kata, format tujuan, evaluasi dan gambar, video, audio dan animasi. Perancangan Emodul disesuaikan dengan hasil analisis kebutuhan, analisis silabus, dan analisis mahasiswa. Setelah tahap design selesai, selanjutnya dilakukan tahap development. Tahap ketiga yaitu development ini dilakukan untuk mendapatkan e-modul yang valid, praktis, dan efektif. Tahap ini terdiri dari uji validitas dan uji reliabilitas yang diperoleh dari penilaian validator, uji praktikalitas yang diperoleh dari penilaian 
dosen mata kuliah dan mahasiswa dalam menggunakan e-modul, dan yang terakhir tahap uji efektifitas emodul yang diperoleh dari nilai evaluasi mahasiswa pada materi pembelajaran. Analisis efektifitas emodul pembelajaran berbasis Android dilakukan untuk mengetahui tingkat keefektifan e-modul yang diterapakan dalam pembelajaran. Analisis efektivitas e-modul dilihat dari ketuntasan klasikal yang diperoleh dengan membandingkan hasil post-test dengan nilai KKM yang ditetapkan. Penentuan efektivitas E-modul pembelajaran Food Control adalah jika persentasi ketuntasan klasikal mahasiswa lebih besar atau sama dengan 85\% maka E-modul Food Control efektif digunakan. Dapat disimpulkan berdasarkan nilai KKM hasil belajar setelah menggunakan e-modul dinyatakan tuntas dan e-modul berbasis Android dikategorikan efektif.

E-modul dikatakan efektif karena tingkat kelulusan mahasiswa dalam satu kelas sama atau lebih dari 85\%. Berdasarkan hasil analisis yang diuraikan diperoleh rata-rata ketuntasan mahasiswa sebesar 96,55\%. Hal ini menunjukkan ketuntasan klasikal telah tercapai, dapat disimpulkan bahwa e-modul berbasis Android efektif digunakan apabila ditinjau dari ketuntasan klasikal. Kemudian Efektivitas Berdasarkan Nilai Gain Score.Nilai gain score dilihat dari jumlah peningkatan hasil belajar mahasiswa setelah pretest dan posttest. E-modul berbasis Android dikatakan efektif. Dari hasil rekapitulasi hasil belajar mahasiswa dengan rata-rata gain score dengan nilai 0,702 yaitu dalam kategori tinggi. Sehingga dilihat dari hasil belajar kognitif mahasiswa yang mengikuti mata kuliah dengan menggunakan E-modul, menunjukkan bahwa E-modul pembelajaran Food Control yang dikembangkan peneliti efektif untuk meningkatkan hasil belajar mahasiswa.

Pengujian efektifitas e-modul berbasis Android melalui pengujian ketuntasan klasikal, dan gain score. Pedoman pengukuran tingkat efektivitas penggunaan e-modul yang dikembangkan dilihat dari persentase nilai ketuntasan hasil belajar yang diperoleh mahasiswa setelah selesai melaksanakan pembelajaran dengan menerapkan e-modul berbasis Android. Nilai persentase ketuntasan hasil belajar mahasiswa diperoleh berdasarkan kegiatan ujian (test) yang dilaksanakan sebelum dan sesudah melakukan pembelajaran dengan e-modul. Berdasarkan pengujian gain score diperoleh nilai sebesar 0,70 dengan kategori tinggi. Maka dapat disimpulkan bahwa e-modul berbasis Android pada mata kuliah Food Control dinyatakan efektif. Setelah dilaksanakan tahapan define, design dan develop, tahap terakhir yang peneliti lakukan yaitu tahapan disseminate. (penyebaran). Setelah e-modul yang dirancang memperoleh hasil valid, praktis dan efektif, maka e-modul pembelajaran sudah dapat dikatakan layak untuk disebarkan. E-modul yang sudah siap dapat disebarkan atau digunakan oleh kelas yang lain yang mempunyai mata kuliah yang sama. Penyebaran dilakukan dengan memberikan e-modul kepada dosen pengampuh mata kuliah Food Control untuk diterapkan di perkuliahan.

\section{Pembahasan}

E-modul merupakan salah satu media pembelajaran yang dapat digunakan oleh guru dalam pembelajaran. E-modul adalah alat bantu yang didalamnya berisikan sebuah materi pembelajaran yang proses pengembagannya dirancang dengan sistematis dan menarik sehingga dapat mencapai kompetensi yang diharapkan (Irwansyah et al., 2017; Sriyanti et al., 2021; Triwahyuningtyas et al., 2020). E-modul merupakan perpaduan teknologi cetak dan digital sehingga dapat mengajarkan siswa untuk belajar menggunakan teknologi untuk belajar (Asmi et al., 2018; Cloonan et al., 2020; Winatha et al., 2018). Emodul dapat didefinisikan sebagai penyajian bahan belajar siswa yang dapat dipelajari secara mandiri dan disusun dengan sistematis untuk mencapai tujuan pembelajaran (Ningsih \& Mahyuddin, 2021; Sidiq \& Najuah, 2020; Sofyan et al., 2019). E-modul merupakan salah satu media digital berbasis teknologi. Dalam proses pembelajaran E-modul digunakan sebagai penyedia informasi dasar karena menyajikan berbagai materi pokok. Selain itu E-modul juga sebagai bahan instruksi kepada siswa yang menyajika bahan ajar secara lengkap dengan gambar yang menarik (Aprilia \& Suryadarma, 2020; Aufa et al., 2021; Subarkah et al., 2021). Kegunaan E-modul lainnya yaitu melatih peserta didik untuk menilai kemampuannya sendiri melalui tes yang telah disajikan pada E-modul (Hamid et al., 2021; Hamzah \& Mentari, 2017). Hal ini yang menyebabkan E-modul menarik dan sangat dibutuhkan dalam pembelajaran. Selain itu penggunaan Emodul juga menyebabkan peran dosen tidak terlalu dominan dalam kegiatan belajar. Keunggulan E-modul lainnya yaitu mengakomodasi berbagai kecepatan belajar ssiwa (Ningsih \& Mahyuddin, 2021; Suarsana \& Mahayukti, 2013; Sunismi \& Fathani, 2016). Siswa yang memiliki kecepatan belajar tinggi maka akan lebih cepat menyelesaikan modul ataupun lebih mudah memahami isi modul. Sebaliknya,siswa yang lambat diberikan kemudahan untuk mengulang materi pembelajaran sesuai dengan keinginan sehingga siswa lebih mudah memahami materi pembelajaran. Hal ini yang menyebabkan mahasiswa lebih mudah dalam memahami materi pembelajaran.

Hal tersebut sejalan dengan penelitian sebelumnya yang menyatakan bahwa E-modul dapat membangun, memicu, memperkuat minat mahasiswa untuk belajar secara mandiri dan proses pembelajaran lebih efektif, efesiensi sehingga terjadi peningkatan kualitas pembelajaran (Darmayasa et 
al., 2018; Sidiq \& Najuah, 2020). Temuan penelitian lainnya juga menyatakan bahwa media pembelajaran dinyatakan sangat efektif karena bisa meningkatkan hasil belajar siswa yang dinyatakan dengan nilai siswa yang berada di atas KKM (Faridah \& Santi, 2021). Berdasarkan penelitian yang dilakukan dan penelitian relevan oleh peneliti lain sama-sama membuktikan bahwa E-modul dapat meningkatkan hasil belajar mahasiswa. Perbedaan antara penelitian ini dengan penelitian relevan terletak pada objek penelitian dan mata kuliah yang diteliti. Namun secara keseluruhan penelitian ini dan penelitian relevan sama-sama membuktikan keberhasilan dari penggunaan e-modul yang dikembangkan. Melalui penggunaan e-modul dalam proses pembelajaran dapat membantu mahasiswa dalam memahami materi lebih baik dan pembelajaran lebih efektif. Berdasarkan analisis yang dilakukan pada tahap uji efektifitas membuktikan penggunaan e-modul dalam proses pembelajaran dapat membantu mahasiswa dalam memahami materi lebih cepat dan meningkatkan motivasi dalam belajar mandiri bagi mahasiswa karena mahasiswa sudah memiliki bekal dengan materi yang dibahas. E-modul yang menyediakan teks yang ringan untuk dipahami, serta gambar yang memberi pemahaman bagi mahasiswa lebih baik, video yang tersedia dalam e-modul juga memberi referensi bagi mahasiswa.

\section{SIMPULAN}

E-modul berbasis Android yang telah dikembangkan mendapatkan validitas sangat baik dari ahli dan siswa sehingga layak diterapkan dalam proses pembelajaran. Selain itu, E-modul berbasis Android efektif digunakan dalam pembelajaran karena membantu mahasiswa dalam belajar dan berpengaruh pada hasil belajar mahasiswa yang meningkat.

\section{DAFTAR PUSTAKA}

Abidah, A., Hidaayatullaah, H. N., Simamora, R. M., Fehabutar, D., \& Mutakinati, L. (2020). The Impact of Covid-19 to Indonesian Education and Its Relation to the Philosophy of "Merdeka Belajar." Studies in Philosophy of Science and Education, 1(1), 38-49. https://doi.org/10.46627/sipose.v1i1.9.

Aprilia, I., \& Suryadarma, I. G. P. (2020). E-Module of Mangrove Ecosystem (EMME): Development, Validation, and Effectiveness in Improving Students' Self-Regulated. Biosfer : Jurnal Pendidikan, 13(1), 114-129. https://doi.org/10.21009/biosferjpb.v13n1.114-129.

Asmi, A. R., Dhita Surbakti, A. N., \& C., H. (2018). E-Module Development Based Flip Book Maker For Character Building In Pancasila Coursework Sriwijaya University. Jurnal Pendidikan Ilmu Sosial, 27(1), 1-10. https://doi.org/10.17509/jpis.v27i1.9395.

Aufa, M. N., Rusmansyah, R., Hasbie, M., Jaidie, A., \& Yunita, A. (2021). The Effect of Using e-module Model Problem Based Learning (PBL) Based on Wetland Environment on Critical Thinking Skills and Environmental Care Attitudes. Jurnal Penelitian Pendidikan IPA, 7(3), 401-407. https://doi.org/10.29303/jppipa.v7i3.732.

Candra Lestari, N. P. (2018). Penerapan Model Pembelajaran Kooperatif Tipe Nht Berbantuan Media Audio Visual Untuk Meningkatkan Hasil Belajar IPA. Journal of Education Action Research, 2(4), 355. https://doi.org/10.23887/jear.v2i4.16331.

Cloonan, M. R., Cloonan, D. J., Schlitzkus, L. L., \& Fingeret, A. L. (2020). Learners with Experience in Surgical Scrub Benefit from Additional Education with an Interactive E-Learning Module. Journal of the American College of Surgeons, 4(2). https://doi.org/10.1016/j.jamcollsurg.2020.08.521.

Darmayasa, I. K., Jampel, N., Simamora, A. H., \& Pendidikan, J. T. (2018). Pengembangan E-Modul Ipa Berorientasi Pendidikan Karakter di SMP Negeri 1 Singaraja. Jurnal Edutech Undiksha, 6(1), 5365. https://doi.org/10.23887/jeu.v6i1.20267.

Devi, S., Bhat, Ks., Ramya, S., Ravichandran, K., \& Kanungo, R. (2016). Self-directed learning to enhance active learning among the 2nd -year undergraduate medical students in Microbiology: An experimental study. Journal of Current Research in Scientific Medicine, 2(2), 80-83. https://doi.org/10.4103/2455-3069.198379.

Dewa, E., Maria Ursula Jawa Mukin, \& Oktavina Pandango. (2020). Pengaruh Pembelajaran Daring Berbantuan Laboratorium Virtual Terhadap Minat dan Hasil Belajar Kognitif Fisika. JARTIKA Jurnal Riset Teknologi Dan Inovasi Pendidikan, 3(2), 351-359. https://doi.org/10.36765/jartika.v3i2.288.

Faridah, A., \& Santi, T. D. (2021). Praktikalitas dan Efektivitas Pengembangan Mobile Learning Berbasis Moodle pada Mata Pelajaran Pengetahuan Bahan Makanan di Sekolah Menengah Kejuruan. Edukatif: Jurnal Ilmu Pendidikan, 3(5), 2194-2199.

Febliza, A., \& Okatariani, O. (2020). The Development of Online Learning Media by Using Moodle for General Chemistry Subject. Journal of Educational Science and Technology (EST), 6(1), 40. 
https://doi.org/10.26858/est.v6i1.12339.

Fisnani, Y., Utanto, Y., \& Ahmadi, F. (2020). The Development of E-Module for Batik Local Content in Pekalongan Elementary School. Innovative Journal of Curriculum and Educational Technology, 9(1), 40-47. https://doi.org/10.15294/IJCET.V9I1.35592.

Fitriyani, Y., Fauzi, I., \& Sari, M. Z. (2020). Motivasi Belajar Mahasiswa Pada Pembelajaran Daring Selama Pandemik Covid-19. Profesi Pendidikan Dasar, 7(1), 121-132. https://doi.org/10.23917/ppd.v7i1.10973.

Fortuna, A. P., Rida, A. M., Maharani, L. S. P., Ardiansyah, R., \& Sari, A. A. (2020). A needs analysis of digital connecting book in education in the pandemic era. ACM International Conference Proceeding Series. https://doi.org/10.1145/3452144.3452154.

Hamid, S. N. M., Lee, T. T., Taha, H., Rahim, N. A., \& Sharif, A. M. (2021). E-Content Module For Chemistry Massive Open Online Course (Mooc): Development And Students' Perceptions. Journal of Technology and Science Education, 11(1), 67-92. https://doi.org/10.3926/jotse.1074.

Hamzah, I., \& Mentari, S. (2017). Development of Accounting E-Module to Support the Scientific Approach of Students Grade X Vocational High School. Journal of Accounting and Business Education, 1(1), 78. https://doi.org/10.26675/jabe.v1i1.9751.

Irwansyah, F. S., Lubab, I., Farida, I., \& Ramdhani, M. A. (2017). Designing Interactive Electronic Module in Chemistry Lessons. Journal of Physics: Conference Series, 895(1). https://doi.org/10.1088/17426596/895/1/012009.

Jang, M., Aavakare, M., Nikou, S., \& Kim, S. (2021). The Impact of Literacy on Intention to Use Digital Technology for Learning: A Comparative Study of Korea and Finland. Telecommunications Policy, 45(7). https://doi.org/10.1016/j.telpol.2021.102154.

Laksana, D. N. L. (2020). The Implementation Of Online Learning During COVID-19 Pandemic: Student Perceptions In Areas With Minimal Internet Access. Journal of Education Technology, 4(4), 502509. https://doi.org/10.23887/jet.v4i4.29413.

Logan, R. M., Johnson, C. E., \& Worsham, J. W. (2021). Development of an E-learning Module to Facilitate Student Learning and Outcomes. Teaching and Learning in Nursing, 16(2), 139-142. https://doi.org/10.1016/j.teln.2020.10.007.

Lyashenko, M. S., \& Malinina, I. A. (2015). The Use of Learning Management System Projects for Teaching a Foreign Language in the University. Procedia - Social and Behavioral Sciences, 182, 81-88. https://doi.org/10.1016/j.sbspro.2015.04.741.

Mastroleo, N. R., Humm, L., Williams, C. M., \& Kiluk, B. D. (2020). Initial Testing of a Computer-Based Simulation Training Module to Support Clinicians' Acquisition of CBT Skills for Substance use Disorder Treatment. Journal of Substance Abuse Treatment, 114. https://doi.org/10.1016/j.jsat.2020.108014.

Ningsih, S. Y, \& Mahyuddin, N. (2021). Desain E-Module Tematik Berbasis Kesantunan Berbahasa Anak Usia Dini di Taman Kanak-Kanak. Jurnal Obsesi : Jurnal Pendidikan Anak Usia Dini, 6(1), 137-149. https://doi.org/10.31004/obsesi.v6i1.1217.

Ningsih, Sri Yunimar, \& Mahyuddin, N. (2021). Desain E-Module Tematik Berbasis Kesantunan Berbahasa Anak Usia Dini di Taman Kanak-Kanak. Jurnal Obsesi : Jurnal Pendidikan Anak Usia Dini, 6(1), 137149. https://doi.org/10.31004/obsesi.v6i1.1217.

Onyema, E. M. (2020). Impact of Coronavirus Pandemic on Education. Journal of Education and Practice, 11(13), 108-121. https://doi.org/10.7176/jep/11-13-12.

Padmadewi, N. N. (2015). Pengembangan Perangkat Pembelajaran Berbasis Pendidikan Karakter Untuk Mata Kuliah Strategi Pembelajaran Bahasa Jurusan Pendidikan Bahasa Jepang Di Universitas Pendidikan Ganesha Singaraja. JPI (Jurnal Pendidikan Indonesia), 4(1), 540-555. https://doi.org/10.23887/jpi-undiksha.v4i1.4893.

Pratama, G. S., \& Retnawati, H. (2018). Urgency of Higher Order Thinking Skills (HOTS) Content Analysis in Mathematics Textbook. Journal of Physics: Conference Series, 1097(1). https://doi.org/10.1088/1742-6596/1097/1/012147.

Puspitarini, Y. D., \& Hanif, M. (2019). Using Learning Media to Increase Learning Motivation in Elementary School. Anatolian Journal of Education, 4(2), 53-60. https://doi.org/10.29333/aje.2019.426a.

Raharjo, M. W. C., Suryati, S., \& Khery, Y. (2017). Pengembangan E-Modul Interaktif Menggunakan Adobe Flash Pada Materi Ikatan Kimia Untuk Mendorong Literasi Sains Siswa. Hydrogen: Jurnal Kependidikan Kimia, 5(1), 8. https://doi.org/10.33394/hjkk.v5i1.102.

Sahin, D., \& Yilmaz, R. M. (2020). The effect of Augmented Reality Technology on middle school students' achievements and attitudes towards science education. Computers \& Education, 144. https://doi.org/10.1016/j.compedu.2019.103710.

Setianingsih, I. G. A. A. A., Putra, D. K. N. S., \& Kt.Ardana, I. (2019). Pengaruh Model Pembelajaran 
Reciprocal Teaching Berbantuan Media Audio Visualterhadap Kompetensi Pengetahuan IPA. Journal of Education Technology, 3(3), 203-209. https://doi.org/10.23887/jet.v3i3.21827.

Sidiq, R., \& Najuah. (2020). Pengembangan E-Modul Interaktif Berbasis Android Pada Mata Kuliah Strategi Belajar Mengajar. Jurnal Pendidikan Sejarah, 9(1), 1-14. https://doi.org/10.21009/JPS.091.01.

Slovaček, K. A., \& Čosić, G. (2020). The Role of Parents during the COVID19 Pandemic in Croatia. Studies in Educational Management, 8(8), 9-17. https://doi.org/10.32038/sem.2020.08.02.

Sofyan, H., Anggereini, E., \& Saadiah, J. (2019). Development of E-Modules Based on Local Wisdom in Central Learning Model at Kindergartens in Jambi City. European Journal of Educational Research, 8(4), 1137-1143. https://doi.org/10.12973/eu-jer.8.4.1137.

Sriyanti, I., Almafie, M. R., Marlina, L., \& Jauhari, J. (2021). The effect of Using Flipbook-Based E-modules on Student Learning Outcomes. Kasuari: Physics Education Journal (KPEJ), 3(2), 69-75. https://doi.org/10.37891/kpej.v3i2.156.

Suarsana, I. M., \& Mahayukti, G. A. (2013). Pengembangan E-Modul Berorientasi Pemecahan Masalah Untuk Meningkatkan Keterampilan Berpikir Kritis Mahasiswa. Jurnal Nasional Pendidikan Teknik Informatika (JANAPATI), 2(3), 193. https://doi.org/10.23887/janapati.v2i3.9800.

Subarkah, C. Z., Alhak, A. A., Sari, S., Ruswandi, U., \& Rochman, C. (2021). Developing E-module on the Topic of Integrated Addictive Substances with Islamic Values. JTK (Jurnal Tadris Kimiya), 6(1), 1625. https://doi.org/10.15575/jtk.v6i1.9802.

Sunismi, S., \& Fathani, A. H. (2016). Uji Validasi E-Module Matakuliah Kalkulus I untuk Mengoptimalkan Student Centered Learning dan Individual Learning Mahasiswa S-1. Jurnal Review Pembelajaran Matematika, 1(2), 174-191. https://doi.org/10.15642/jrpm.2016.1.2.174-191.

Surata, I. K., Sudiana, I. M., \& Sudirgayasa, I. G. (2020). Meta-Analisis Media Pembelajaran pada Pembelajaran Biologi. Journal of Education Technology, 4(1), 22-27. https://doi.org/10.23887/jet.v4i1.24079.

Susilowati, E., \& Azzasyofia, M. (2020). The parents stress level in facing children study from home in the early of covid-19 pandemic in Indonesia. International Journal of Science and Society, 2(3), 1-12. https://doi.org/10.200609/ijsoc.v2i3.117.

Syarifudin, A. S. (2020). Impelementasi Pembelajaran Daring Untuk Meningkatkan Mutu Pendidikan Sebagai Dampak Diterapkannya Social Distancing. Jurnal Pendidikan Bahasa Dan Sastra Indonesia Metalingua, 5(1), 31-34. https://doi.org/10.21107/metalingua.v5i1.7072.

Tiwery, W. Y., Patty, F. N., \& Nanlohy, D. F. (2021). Role Of Family For Children's Education During A Pandemic In Eastern Indonesia. Turkish Journal of Computer and Mathematics Education (TURCOMAT), 12(7), 1522-1527. https://doi.org/10.17762/turcomat.v12i7.2965.

Triwahyuningtyas, D., Ningtyas, A. S., \& Rahayu, S. (2020). The problem-based learning e-module of planes using Kvisoft Flipbook Maker for elementary school students. Jurnal Prima Edukasia, 8(2), 199208. https://doi.org/10.21831/jpe.v8i2.34446.

Winatha, K. R., Naswan, S., \& Ketut, A. (2018). Pengembangan E-modul Interaktif Berbasis Proyek Pada Mata Pelajaran Simulasi Digital Kelas X di SMK TI Bali Global Singaraja. Jurnal Teknologi Pembelajaran Indonesia, 8(1). https: //doi.org/10.23887/jtpi.v8i1.2238.

Wungguli, D., \& Yahya, L. (2020). Pengaruh Penggunaan Media Berbasis Information and Communication Technology (ICT) terhadap Hasil Belajar Siswa pada Materi Dimensi Tiga. Jambura Journal of Mathematics Education, 1(1), 41-47. https://doi.org/10.34312/jmathedu.v1i1.5376.

Yusuf Siregar, M., \& Amiril Akbar, S. (2020). Strategi guru dalam meningkatkan kualitas mengajar selama masa Pandemi COVID-19. At- Tarbawi, 180-188. https://doi.org/10.32505/tarbawi.v12i2.1832. 